Pamiętnik Literacki 2018, 2, s. 29-48

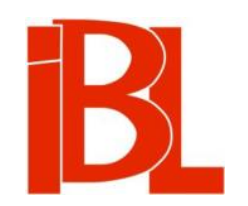

\title{
Domowy wróg i sojusznik. Turcja Mickiewicza
}

\author{
Jarosław Ławski
}


Pamiętnik Literacki CIX, 2018, z. 2, PL ISSN 0031-0514

DOI:10.18318/pl.2018.2.2

JAROSŁAW ŁAWSKI Uniwersytet w Białymstoku

\title{
DOMOWY WRÓG I SOJUSZNIK TURCJA MICKIEWICZA
}

\author{
Drżą pola przed armatą, dąbrowy blednieją, \\ Bukowiny na zbroje oka wznieść nie śmieją. \\ I Turczyn, jako chytra liszka ogon kryje \\ W jamie, tak i ów chowa w okopie swą szyję ${ }^{1}$.
}

Łatwo i niełatwo mówić o Turcji Mickiewicza, jego obrazie Turków. Jest to nieskomplikowane, bo informacji znajdziemy na ów temat bardzo dużo, a liczba kategorii, jakie można przyłożyć do takiego zarysu, okazała: Orient, Azja, islam, Wschód, wróg, przedmurze... Wszystkie je wolno stosować do analizy Turcji poety, ale - dopowiedzmy - właśnie one ów wątek wyczerpują. Trudno mówić o Turcji Mickiewicza, bo wszystko wydaje się tu zbyt proste: materiał, jaki przynoszą same prelekcje paryskie, jest ogromny. Wystarczą proste rekonstrukcje tego, „co myślał romantyk”, i... obraz gotowy. To pozory!

Owóż godzi się stwierdzić, że trudno o bardziej złożone i zaskakujące zjawisko niż Mickiewicza nie tyle obraz, ile przeżywanie fenomenu Turcji. Był to dla poety temat, jak go nazwałem, domowy i osobisty - autor Renegata. (Ballady tureckiej) nigdy nie wpisał Turcji w zimne kalkulacje polityczne czy w konstrukcje historiozoficzne unoszące się ponad rzeczywistością historii, choć po 1832 roku i na Turków spozierał okiem mesjanisty. Można rzec, iż Turcja oraz elementy jej kultury towarzyszyły poecie od urodzenia do śmierci. Zmarł, jak wiadomo, w Stambule, gdzie do dziś ma niewielkie muzeum (Istanbul, Adam Mickiewicz Müzesi) ${ }^{2}$.

Zanim się tej bliskości polsko-tureckiej przyjrzę, kilka obserwacji ogólnych. Po pierwsze, obraz Turcji i Turków okazuje się u pisarza spójny, ewoluujący. Nie znajdujemy w nim niczego z paradoksów historycznych. Natomiast zaskakuje co innego: jest to wizja wrogiej cywilizacji, którą Mickiewicz ocenia nader pozytywnie. Nie ma w tym, co wyjaśnię, żadnych sprzeczności.

Po drugie, Mickiewicza nie cechuje w ogóle stosunek, który nazwalibyśmy an-

1 S. S. Szemiot, Moc i ręka Boska $w$ odwadze polskiej i litewskiej okazana $w$ dzień biskupa turońskiego Marcina świętego, Anno 1673, 11 Novembris, pod Chocimem. W: Sumariusz wierszów. Wyd. oprac. M. Ko rolko. Warszawa 1981, s. 228.

2 Zob. S. Körpe, Reserches and Studies of Adam Mickiewicz's Life and Work in Turkey; M. Ma słow s ki, La Mort de Mickiewicz; J. O d r ow ąż - Pi e n i ąż e k, L’Histoire du Musée Adam Mickiewicz d'Istanbul. W zb.: Mickiewicz - Turcja - Europa / Mickiewicz - Türkiye - Avrupa. Red. J. Pietrzak-Thébault. Współpr. S. Körpe, A. Sarkady, A. Ayşen Kaim. Warszawa 2012. 
tykwaryczno-muzealniczym. Nie zbiera szabel tureckich, nie wydaje, jak Józef Ignacy Kraszewski, dawnych relacji z podróży do Stambułu ${ }^{3}$, autora Sonetów krymskich nawet niezbyt ciekawią domysły i swary historiografów XIX-wiecznych. Wprawdzie Mickiewicz wiele o tym czytał, ale Turcja jest dlań nade wszystko wrogiem honorowym a okrutnym, w starciu z którym wyrabiała się tożsamość Sarmatów-mesjanistów, obrońców Europy (dawniej i dziś przed zgnilizną moralną). Podkreślam: Mickiewicz stale doświadcza Turcji, tureckości, nie zaś ją abstrakcyjnie percypuje.

Po trzecie, nie sposób rozważań na ten temat umocować w tak rozplenionej badawczo kategorii jak orientalizm (szczególnie - „studia postkolonialne”) ${ }^{4}$. Owszem, literacko wykorzystane motywy turecko-orientalne można nazwać orientalizmem, a nawet turkizmem czy egzotyzmem. Ale co to powie o Mickiewiczu-poecie, polityku, mesjaniście? Niewiele. Wolno też pomyśleć rzecz nie do pomyślenia: to nie Mickiewicz kreował obraz Turcji z pozycji „pana”, europocentrycznego rozdawcy ról kulturowych, lecz to Turcja opanowała jego wyobraźnię, jego samego. To bliższe rzeczywistości. Orientalizm, turkizm Mickiewicza byłby więc owładnięciem wieszcza przez turecki Wschód, a nie odwrotnie.

Naturalnie, znajdziemy u poety wszystkie przedstawienia Turcji i Turków, które zdominowały w owym czasie wyobraźnię zbiorową. Po kolei będą to:

- Turcja jako śmiertelne zagrożenie dla Rzeczypospolitej i chrześcijańskiej Europy.

- Turcja jako kraj ujarzmiający Bałkany, w tym ludy słowiańskie: Bułgarów, Serbów, Chorwatów, Czarnogórców, a zagrażający Węgrom, Austrii i Mołdawii.

- Turcja dążąca do zawładnięcia zmityzowaną przestrzenią Czarnomorza, wybrzeżami Morza Czarnego, na których panowała niegdyś Rzeczpospolita po unii z Litwą (tu: Krym, Budżak, Besarabia) ${ }^{5}$.

- Turcy jako reprezentanci żywiołu azjatyckiego, obcego indoeuropejskiej kulturze Europy; Turcy są tu wędrowcami-przybyszami z Azji Środkowej, cechujacymi się okrucieństwem ${ }^{6}$.

3 J. I. Kr a s z e w s ki, Podróże i poselstwa polskie do Turcji, a mianowicie: podróż E. Otwinowskiego 1557, Jędrzeja Taranowskiego komornika j. k. m. 1569 i poselstwo Piotra Borowskiego 1568. Przygotowane do druku z rękopismu przez ... Kraków 1860.

4 Zob. J. B a c hór z, O polskim egzotyzmie romantycznym. W zb.: Problemy polskiego romantyzmu. Praca zbiorowa. Seria 2. Red. M. Ż migrodzka. Wrocław 1974. - C. Rowińs ki, Rozważania na temat egzotyzmu $w$ literaturze. W zb.: Orient $w$ literaturze i kulturze modernizmu. Red. E. Ło c h. Lublin 2011.

5 Postacią zmityzowaną w wyobraźni Mickiewicza, przestrzegającą przed Turcją ekspansywną, jest omówiony szczegółowo w prelekcjach paryskich Janczar Polak. Jednak i w jego wizji więcej ambiwalencji niż przestrogi. Zob. J. Ła w s k i, Nie tylko Janczar, ale Polak. Mickiewicz czyta „Pamiętniki Janczara”. W zb.: Miscellanea literackie i teatralne (od Kochanowskiego do Mrożka). Profesorowi Janowi Okoniowi przez przyjaciót i uczniów na 70. urodziny zebrane. Red. K. Pła c h c ińs ka, M. Ku ra n. Cz. 2: Tradycje literackie i teatralne. Łódź 2010, s. 27.

$6 \quad$ Okrucieństwo nie stanowiło patentu tureckiego. Najokrutniejszym władcą na Bałkanach był słynny hospodar Wład II Diabeł, zwany Dracul. Zob. F. B a b in g e r, Z dziejów imperium Osmanów. Sułtan Mehmed Zdobywca i jego czasy. Przeł. T. Zabłudowski. Warszawa 1977, s. 209-211 (tu przykłady okrucieństwa, których nawet cytować się nie chce, ot, choćby: „Jego ulubionym widowiskiem były męczarnie ludzi wbitych na pal” 〈s. 209〉). 
- Turcy jako lud przeciwstawiany, z jednej strony, Mongołom i Tatarom, a z drugiej, Arabom; to przeciwstawienie ma kapitalne znaczenie dla wywodów Mickiewicza, pozwalając zarysować „twórczy” obraz żywiołu tureckiego.

- Turcja jako państwo, które, jak głosi mit historyczny, nigdy nie uznało rozbiorów Rzeczypospolitej, w XIX wieku zaś samo stanęło oko w oko ze śmiertelnym niebezpieczeństwem: imperium rosyjskim, dążącym, przy wykorzystaniu Greków i bałkańskich Słowian, do zawładnięcia cieśninami Bosfor i Dardanele, a w końcu do odzyskania dla chrześcijaństwa wschodniego jego patriarszej stolicy - Konstantynopola, zdobytego przez Turków w 1453 roku? .

- Turcja jako reprezentant wysokiej kultury materialnej, militarnej i literackiej, z którą dawni i XIX-wieczni Polacy prowadzą wymianę dóbr kulturalnych.

- Turcja jako wróg; starcia z nim przyniosły i utrwaliły mityczne obrazy klęsk i tryumfów militarnych: Warny, Cecory, Chocimia, Wiednia; wiktoria wiedeńska stała się dla XIX-wiecznych Polaków źródłem heroicznej i ironicznej świadomości. Oto Austria wyzwolona przy udziale wojsk Jana III Sobieskiego dokona wkrótce rozbiorów Rzeczypospolitej ${ }^{8}$.

Jak widać, wśród tych przedstawień są i nacechowane złowrogo (Turek okrutnik) i wprost bajecznie miłe Turcji (kraj, który nie uznał rozbiorów!). Ewoluujący obraz Turcji apogeum osiagną - teoretycznie - w wykładzie III kursu pierwszego prelekcji w Collège de France, gdzie Mickiewicz wypowiedział wiekopomne słowa o roli Turcji w dziejach Polski i Słowiańszczyzny. Spójrzmy na nie...

\section{Etnogonia Polaków}

Chciałbym od razu odróżnić potwierdzoną przez źródła, dane archeologiczne etc. etnogenezę Słowian i Polaków (indoeuropejską, irańską itd.) ${ }^{9}$ od mającej charakter duchowy, a nawet religijny (prowidencjalistyczny), etnogonii - duchowych narodzin narodowości. Otóż udział w tym znakomitym wydarzeniu, jakim było pojawienie się narodowości polskiej, Mickiewicz przypisał... wojnom z Turcją i Turkami. W wykładach II i III kursu pierwszego prelekcji rzucił Słowian - w tym (przyszłych) Rosjan - na azjatyckie szańce Europy. Stworzył wizję potężnych zmagań z napierającym

7 Zob. M. B ałc zew s ki, Turcja a upadek Polski $w$ XVIII wieku. W zb.: Oświeceni wobec rozbiorów Polski. Red. J. Grobi s. Łódź 1998. Zob. też J. Paj e w s ki, Kilka słów o stosunkach polsko-tureckich $w$ ciagu wieków. W: Buńczuk i koncerz. Z dziejów wojen polsko-tureckich. Warszawa 2006, s. 165: „W wieku XIX powstała nawet legenda, utrzymująca się długo, że Turcja nigdy nie uznała rozbiorów Polski. Istotnie nie ma formalnego aktu prawnego, w którym Porta zajęłaby pozytywne stanowisko wobec dokonanej na Polsce zbrodni. Ale od tego daleko do demonstracji, o której szeroko w Polsce opowiadano, jakoby sułtan przyjmując korpus dyplomatyczny zawsze zapytywał manifestacyjnie: "A gdzie jest poseł Lechistanu? - i zawsze otrzymywał odpowiedź wielkiego wezyra: "Najjaśniejszy Panie, poseł Lechistanu z powodu ważnych przeszkód nie zdążył jeszcze przybyć". Fakt, że legenda ta utrzymywała się tak długo, dowodzi pełnych sympatii i nadziei nastrojów społeczeństwa polskiego względem dawnego przeciwnika”.

8 Wiktoria wiedeńska, trzeba pamiętać, jest słabo zakorzeniona w świadomości dawnych i współczesnych Austriaków.

9 Zob. J. Ław s ki, Sacrum słowiańskie: od „Historii polskiej” do prelekcji paryskich. W: Mickiewicz - mit - historia. Studia. Białystok 2010. Z kolei irańską etnogenezę Słowian szczególnie uwydatnia

Z. Kaźmi e r czy k w książce Słowiańska psychomachia Mickiewicza (Gdańsk 2012). 
na Europę szczepem „mongolsko-tatarskim”. Mongołów/Tatarów ukazał jako zwierzęce bestie pustoszące rodzaca się cywilizację. Starcie z Mongołem/Tatarem było, jego zdaniem, spotkaniem $z$,ideałem biernego posłuszeństwa” (LS-II 27) ${ }^{10}$, który to ideał przejmie Ruś. Opanowani przez genialnych wodzów, takich jak Dżyngis-chan, Mongołowie/Tatarzy pustoszyli Eurazję, wykorzystując swą bezwzględna, zwierzęcą naturę drapieżców:

Stepy Azji, dziś jeszcze noszące nazwę Tatarii, zajmują obszar znacznie większy od całej Europy; ich ludność wynosi zaledwie cztery do sześciu milionów, ale każdy mężczyzna jest żołnierzem. Stamtąd wedle mniemania uczonych przyszedł mit o centaurze, którego w Europie wyobrażano sobie jako człowieka wyrastającego ze zwierzęcia. Tatar jest jeszcze takim człowiekiem-zwierzęciem, takim centaurem. Jest on niekształtny; nogi jego słabe mają na tyle tylko siły, by obejmować konia, na którym spędza całe życie i z którym jakby jedną składa całość. Głowa niezgrabnie kulista jest niby ciężarem przydatnym dla utrzymania równowagi w pędzie. Wzrok jego tchnie tylko zwierzęca namiętnością, a blask oczu podobny do mdłej iskry sczerniałego już i gasnącego węgla. Tatar jest wyzuty z wszelkich pojęć umysłowych, wszelkiego uczucia, $\mathrm{z}$ wszelkich wyobrażeń religijnych; nie znajdujemy u niego ani śladu jakiejkolwiek mitologii ni religii pierwotnej. [LS-II 27]

Zmaganie z tym żywiołem Azji ma - podług Mickiewicza - nieco inny charakter: wspólna jest tu misja obrony chrześcijaństwa, różny przeciwnik...

Ludy słowiańskie rozdzieliły między siebie wielkie posłannictwo obrony chrześcijaństwa. Ruś zmagała się z Mongołami, Polska z Turkami; a jednak wśród tego równoczesnego oporu nie nawiązała się żadna łączność między Rusinami a Polakami. Zwycięstwa i klęski na przemiany po sobie następowały. Nieszczęsna bitwa pod murami Warny, śmierć króla Władysława i kwiatu polskiego rycerstwa pociagnęły za sobą utratę dla chrześcijaństwa Ilirii, Serbii i innych ziem, po czym nastapiły nowe najazdy Turków. Zostali oni wreszcie odrzuceni w wielkiej bitwie pod Chocimiem. Klęska ta jednak jeszcze ich nie powstrzymała i dopiero Jan III, w chwili największego niebezpieczeństwa dla Polski i całego świata chrześcijańskiego, dzięki swemu geniuszowi wojskowemu zachwiał potęgą Osmanów na południu Polski, a później zadał jej ostateczny cios pod murami Wiednia. [LS-II 31]

Owo przesilenie oznacza zarazem ostateczne rozejście się nie tyle cywilizacyjnych $^{11}$, ile duchowych dróg Rusi i Polski. Ta pierwsza bierze z Bizancjum i z Azji zasady bezwzględnego posłuszeństwa, autorytaryzm, imperatyw podboju (w końcu sama podbija Mongolię, zauważa profesor Collège de France). Ta druga odkrywa głęboko religijną wizję: antemurale christianitatis i państwa oraz narodu o charakterze mesjańskim. Ruś ma misję podboju (misjonizm), Rzeczpospolita spełnia

10 Skrótem LS odsyłam do: A. M i c k i e w i c z, Literatura słowiańska. Kurs pierwszy. W: Dzieła. Wyd. Rocznicowe. T. 8. Oprac. J. Maślanka. Przeł. L. Płoszewski. Warszawa 1997. Ponadto stosuję takie skróty na oznaczenie innych dzieł tego autora: $\mathrm{G}=$ Giaur. W: Dzieła poetyckie. T. 2: Powieści poetyckie. Oprac. K. Górs ki. Warszawa 1953; L = Listy. Część czwarta: 1849-1855. W: Dzieła, t. 17 (Oprac. M. Dernałowicz, E. J aworska, M. Zi elińs ka. 2005); P = Pan Tadeusz, czyli Ostatni zajazd na Litwie. Historia szlachecka z roku 1811 i 1812 we dwunastu księgach wierszem. Wyd. 8. Oprac. S. Pig oń. Wrocław 1980. BN I 83; W = Wiersze. W: Dzieła, t. 1 (Oprac. Cz. Zg or zels ki. 1993). Liczby po skrótach wskazują stronice. W przypadku Literatury słowiańskiej liczby rzymskie po łączniku odnoszą się do numerów wykładów, w Panu Tadeuszu - do numerów ksiąg, liczby arabskie zaś sygnalizują stronice.

11 Mickiewicz daje własną definicję cywilizacji, która nie jest dlań „znajomością środków rozwijających siły materialne” i „biegłością w kierowaniu nimi”. Cywilizacja to także stan moralny. O ile pierwsze przysługiwało Dżyngis-chanowi („wycinając w pień całe ludy, oszczędzał rzemieślników i wyrobników [...]"), o tyle drugie - racja moralna - było mu zupełnie obce (LS-II 29). 
posłannictwo Salwatora, republikańskiego mesjasza i herolda wolności (mesjanizm). Jak to możebne, by dwa szczepy słowiańskie obrały tak przeciwne sobie drogi?

Polska zawdzięcza ów mesjański wektor rozwoju (misji mesjańskiej) starciu z Turkami, których Mickiewicz odmalował jako przeciwieństwo Mongołów/Tatarów: „Turcy ze wszystkich pokoleń uralskich najbardziej zbliżają się do plemienia indogermańskiego” (LS-III 33). Jako typ antropologiczny reprezentują azjatyckość uszlachetnioną, a nawet, powiedzielibyśmy, wypięknioną...

Okazałej i szlachetnej postawy, o niezwykłej sile mięśni, lubo nieco miękkiego ciała, Turcy otomańscy w niczym nie są podobni do plemion tatarskich Turkiestanu. Pod względem moralnym także są różni od Mongołów. Jak tamtym zupełnie obce uczucia religijne, tak ci łatwo posuwają się do fanatyzmu; jak tamtych umysł zimny, tak tych wyobraźnia żywa, lubo raczej bierna niż działająca przez się, nic nie tworzy oryginalnie, ale przyswaja, naśladuje płody poezji i sztuki cudzej. Mongoły nie maja żadnego poety, żadnego artysty, podczas gdy Turcy wielki żywią szacunek dla umiejętności. Mongołom jeden tylko w zakresie sztuk należy się wynalazek budownictwa: wieże stawione z ludzi żywych albo uciętych głów ludzkich, zalewanych wapnem. Timur-Leng ${ }^{12}$ własnymi rękoma pomagał mularzom w tej pracy, jak to mówi w jednym $z$ tłumaczeń autor francuski Langlois ${ }^{13}$. Turcy nigdy nie byli tak okrutni; walczyli najczęściej w duchu prozelityzmu, dla rozszerzenia swojej wiary; szczęście zakładali na tym, żeby panować i używać, nie zaś niszczyć. Zapytano raz na radzie mędrców mongolskich, co jest największą rozkoszą w świecie. Sam chan odpowiedział: „Zwyciężyć przeciwnika, w oczach jego znieważyć żonę, pomordować dzieci, i potem samego zamęczyć”. Rada przyznała słuszność monarsze, bo to było pojęcie narodowe.

Turczyn lubi próżniaczy wypoczynek, lubi pogrążać się w słodkim dumaniu. Umiłowany ten stan określa wyrazami nie dającymi się przełożyć, podobnymi do farniente ludów południowych. Turczyn jest chciwy zaborów, bogactwa, łupieży; nigdy jednak nie był tak obrotny jak Mongoł, nigdy nie potrafił korzystać z wynalazków cywilizacji, jakie zastał u ludów podbitych. Brzydzi się obcymi i ten wstręt każe mu gardzić wszystkim, co jest u innych narodów pożytecznego. Mongoły natomiast umieli wyzyskać wyższość, jaką nad nimi miały inne ludy; posłużyli się na przykład puszkarzami chińskimi dla swoich dział. [LS-III 33-34]

Azja jest - co się zapomina - kategorią u Mickiewicza nader ambiwalentną, a raczej poliwalentną. Azja to drapieżczość mongolska, lecz i indoeuropejska kolebka ludów, języków, kultur. To pogaństwo, ale i praźródło wierzeń w jedynego boga, z którego kiedyś wytrysną także na niwie słowiańskiej wiara w Chrystusa, papiestwo, chrystianizm $^{14}$. Turcy reprezentują jeszcze inną Azję - taką, która wędrując do Azji Mniejszej, zmieszała się z napotykanymi ludami. Turcy „posuwają się do fanatyzmu” (LS-III 34), gdy Mongołowie są religijni (to mit, lecz dobrze tu funkcjonujaccy). Choć jawią się jako okrutni zdobywcy, Turcy małoazjatyccy sprawiają wrażenie zorganizowanych: „gdzie raz osiedli, trzymali się uporczywie; co raz zagarnęli, trudno już było im wydrzeć” (LS-III 35). Opatrzność dała Sarmatom inteligentnego i ożywianego uczuciem religijnym przeciwnika, którego słabość stanowi pycha:

Lenormant ${ }^{15}$ powiedział, że ani jeden $z$ władców mongolskich nie miał ducha organizacyjnego; istotnie, umieli oni tylko organizować narzędzia zniszczenia. Turcy, przeciwnie, rozciaggali właściwy

Chodzi tu o Timura, Timur-Langa (1336-1405), w Europie znanego jako Tamerlan. Mowa tu prawdopodobnie o orientaliście francuskim, Louis-Mathieu Langlè sie (1763-1824), który przełożył dzieło Instituts politiques et littéraires de Tamerlan.

Zob. H. Ło w mi ań s ki, Religia Stowian i jej upadek (w. VI-XII). Warszawa 1979. - S. U rbańc zy k, Dawni Stowianie. Wiara i kult. Wrocław 1991.

Charles Le n ormant (1802-1859), archeolog, egiptolog, profesor Collège de France. 
sobie systemat stałego podboju, na swój sposób do pewnego stopnia urządzali kraje zdobyte; gdzie raz osiedli, trzymali się uporczywie; co raz zagarnęli, trudno już było im wydrzeć. Kronikarz, pospolicie znany pod nazwiskiem Janczara Polaka, przyrównywa ich do morza, które ciagle pochłania wody, ale nigdy nie oddaje - podczas gdy wylew Mongołów prędko odpływał na stepy. [LS-III 35]

Mickiewicz zaplątał się w wywodach. Niekiedy już nie wiadomo, czy uważa Turków za lud przebiegły i twórczy, czy leniwy i imitujący innych. Wyjściem z tej sprzeczności jest przypomnienie Janczara Polaka, który od wewnątrz opisał potęgę państwa otomańskiego - bez dwóch zdań, organizmu państwowego lepiej urządzonego niż Rzeczpospolita i większość krajów europejskich. Turcja przedstawiała więc sobą od średniowiecza do XVIII wieku istotną siłę, potęgę. Czyż nie tak samo jak Polska?

W tym momencie, zarysowawszy na tle obrazu animalnych Mongołów obraz Turków o wysokiej kulturze i rozwiniętej duchowości, wyszlachetnionych i chciwych łupów, mógł Mickiewicz wyprowadzić kategorię narodowości. I to jak? Jako wartości wspólnej, jako rozpoznania swej tożsamości w starciu z Turcją:

Parcie kalifatu na Polskę drażniło ją ustawicznie, obudzało wszystkie jej siły, ściskało je do jednego ogniska. Stąd wyrabiało się w Polsce uczucie narodowej potegi i myśl o europejskim powołaniu państwa. Rychło Polacy zrozumieli, że ich powołaniem jest obrona chrześcijaństwa i cywilizacji przeciwko islamizmowi i barbarzyństwu; zaraz musieli poznawać, mierzyć i oceniać swoje siły i środki. Owóż uczucie tych celów, tych wszystkich środków i zasobów, zawarło się w uczuciu na rod ow oś ci i wyraziło sie jednym słowem: oj c zy z na. Patriotyzm jest dogmatem rodzajnym całego duchowego i umysłowego ukształcenia Polaków; ich cała literatura wyrosła, wywinęła się i wykwitła $z$ tego jednego słowa oj c zy zna, jest rozmaitym tej jednej idei stosowaniem i tłumaczeniem. Bo w różnych czasach i w różnych okolicznościach ta idea objawiała się różnym duchom w różnym świetle i w wielorakich postaciach. Natchniony mówca Skarga pojmuje i czuje ojczyznę jako państwo plemienia wybranego, jako Jeruzalem z jej arką, kościołem i stolica, z jej świętą przeszłością, której obrona i zachowanie jest życiem narodu. W opiniach wielu reformatorów dzisiejszych ojczyzna jest to przyszły porządek społe czny, który dopiero tworzyć należy. Wolność, potęga i szczęście wchodzą koniecznie w skład tego wyobrażenia. [LS-III 35-36]

Tak oto konfrontacja z „islamizmem i barbarzyństwem” otworzyła przed Sarmatami droge samozrozumienia, tożsamości, patriotyzmu i pomogła wyklarować pojęcie ojczyzny. Obraz etnogonii, czyli - jak powiedziałby Maurycy Mochnacki - uznania siebie w jestestwie swoim, zawdzięczaja oni położeniu na rubieżach chrystianizmu, stałemu starciu, wojnie. Etnogonia to jej wynik; nieulękniona odwaga wynika zaś z poczucia, wcześniej w walce zrodzonego, narodowej przynależności. Machina dziejów - u Mickiewicza - pracuje z okrucieństwem. W przypadku Rzeczypospolitej: wydaje silne, jak mało gdzie na ziemi, poczucie identyfikacji narodowej. Etnogonia stanowi tu proces skończony, jednorazowy i absolutny. Lecz sam proces historii trwa.

W styczniu 1841, kiedy Mickiewicz głosi wykłady w ramach kursu pierwszego, dzika Ruś, kształcona na doświadczeniu najazdu Mongołów, jest panem świata, podczas gdy i Polska, i Turcja przeżywają lata próby. Pierwsza już się rozpadła, rozdarła, dała się rozszarpać, druga czeka na koniec. Mickiewicz notuje geopolityczną stratę ziem, które Rzeczpospolita przez wieki zdobywała, z melancholią i frasunkiem:

Tak samo przez długi czas losy Polski podobne były do losów Francji. Polska również nie utrzymała nic ze swoich zdobyczy na niewiernych; zachowała tylko przesławne wspomnienia i zyskała u naro- 
dów wielką przychylność. Ludy przywykły widzieć w Polsce przedstawicielkę szlachetnej idei, walcząca za sprawę powszechną.

Na koniec Czechy i Rosja zbliżają się poniekąd do Niemiec; można by powiedzieć, że są to słowiańskie Niemcy. [LS-IV 52]

Odnieść trzeba wrażenie, że nawet misja mesjasza narodów - samotnego zbawcy nie chcących zbawienia Europejczyków - nie przynosi tu ukojenia ${ }^{16}$. Widać, że świadomość mesjanisty wciąż dojrzewa - rozwinie się zaś aż po wizję federacji francusko-rosyjskiej, a w końcu aż po stambulskie doświadczenie walki $z$ imperium. Walki wspólnej: Turków, Polaków, Kozaków, Żydów, Bułgarów, Czerkiesów, Iliryjczyków... W stolicy Turcji będzie Mickiewiczowi - w najgłębszym tego słowa znaczeniu - dobrze. Nie tłumaczy owego faktu tylko wypowiedziana w prelekcjach wizja etnogonii, której akuszerką stała się Turcja. Przyczyn znaleźlibyśmy więcej. Znajdźmy je.

\section{Orient bliski, najbliższy...}

Wypowiedzenie w styczniu 1841 w Paryżu zdumiewających zdań o zaletach Turków (na tle Mongołów, których nietrafnie i krzywdząco utożsamiano z Tatarami) ${ }^{17}$ możliwe było tylko pod warunkiem znajomości owych Turków, ich kultury. Stwierdzenie natomiast, że polski patriotyzm wykuwał się w wojnach $\mathrm{z}$, islamizmem i barbarzyństwem" (czytaj: Turkami), nie tylko nie ubliżało Turkom, lecz ich nobilitowało. Oto autor Sonetów krymskich zakreślił obraz wroga mającego wady, ale ostatecznie i silnego, i... uduchowionego (wprawdzie na pogańską modłę podług poety). Źródłem tych sądów - jakże ważnych sądów, za które spotkała go krytyka emigrantów, uwewnętrzniających inne pojęcia o patriotyzmie i jego źródłach - było bezpośrednie doświadczenie Mickiewicza. Podkreślam: to, co nazywamy i dziś Orientem, stanowiło domową rzeczywistość poety.

Mickiewicz od dzieciństwa związany był z Nowogródkiem. Społeczność miasteczka w dużej części stanowili Muślimowie (litewscy Tatarzy), mający tu drewniany meczet. Tatarzy, dopowiedzmy, pochodzenia tureckiego, lecz na Litwie w liturgii posługujacy się językiem arabskim. Był więc Mickiewicz, już od małego obeznany z Tatarami. Także $z$ jeszcze liczniejszymi w Nowogródku Żydami - przy czym chrześcijanie wszystkich konfesji stanowili w Nowogródku ledwie 29\% ludności ${ }^{18}$. „Orient” znajdował się zatem tu, na miejscu, w domu. To był Orient tureckiego ludu - Tatarów. Ale nie tylko.

16 Na sprzeczności, aporie, pęknięcia postawy mesjanistycznej wielokrotnie wskazywano. Zob. A. W a li cki, Problem religii $w$ ideologiach „Polski odradzajacej się”: od deizmu do mesjanizmu. W: Mesjanizm Adama Mickiewicza w perspektywie porównawczej. Warszawa 2006. - J. Ła w s k i, Mickiewicz, wspólnota, historia. W: Mickiewicz - mit - historia. - J. He r1th, Nad przepaścia historii. Watki katastroficzne $w$ retoryce mesjanizmu polskiego, „Pamiętnik Literacki” 2011, z. 1.

17 Udział Tatarów w wojnach Mongołów sprawił, iż utożsamiano Tatarów z Mongołami. Także nazwa przeszła z Tatarów na Mongołów. Zob. J. Talko - H ry n cew i c z, Muślimowie, czyli tak zwani Tatarzy litewscy. Kraków 1924.

18 Zob. J. M. Rymkiewicz, Nowogródek. W: J. M. Rymkiewicz, D. Siwicka, A. Witkowska, M. Zi elińs ka, Mickiewicz. Encyklopedia. Warszawa 2010, s. 354: „Wydana w roku 1817 Statystyka guberni litewsko-grodzieńskiej Ignacego Lachnickiego informuje, że w Nowogród- 
Litwę i Krym zamieszkiwała i wtedy, i dziś liczna społeczność Karaimów, obecnych choćby w Trokach, posługujących się językiem należącym do grupy języków tureckich (używanym również na Litwie w liturgii). Wizyta w Trokach, w XVIII-wiecznej kienesie, zapewne uświadamiała Mickiewiczowi, z jak niezwykłym religijno-kulturowym zjawiskiem się stykał. Zjawiskiem pogranicznym, między hebrajską a turecką kulturą, między chrześcijaństwem, islamem a judaizmem. Taki też był bliski, domowy Orient Mickiewicza. Nie mam wątpliwości, że to środowisko nowogródzkie ukształtowało w nim tak potem światłą, w ogóle wyprzedzającą i jego, i nasze czasy postawę wobec Turków, Żydów, Karaimów oraz wszystkich „innych”, których bali się jego rodacy, co zresztą (owe dobre i „złe” związki) często wydobywali uczeni i pisarze - Karaimowie i Żydzi XX-wieczni ${ }^{19}$.

Nic dziwnego, że u kresu życia dostrzeże Mickiewicz w Stambule taki wielki Nowogródek - wielonarodowy, nieporządny, zabłocony, ale s wój.

Druga warstwa tureckich elementów w świadomości Mickiewicza wiąże się ze szkołą dominikańską, gdzie przecież odbywał kurs historii, a potem ze studiami w Wilnie. Tu poznawał Turcję mitów, topoi, historiograficzną; przyswajał całe zwroty o Turczynach i Turku, którego ojcowie bili, z którym wojowali. W Słowniku języka Adama Mickiewicza czytamy:

Pobić Turki i Szwedy, wytępić Krzyżaków. [Mieszko ksiązę Nowogródka ${ }^{20}$, w. 21]

Za cóż na widok Kiejstutowéj burki / Drżą Niemce i bledną Turki? [Grażyna, przypis 22]

Że musiała być wojna - przeciw komu? kiedy? / Trudno zgadnać, zapewne z Turkami albo Szwedy [Popas $w$ Upicie $^{21}$.

Turek i Turcja symbolizują wtedy wojnę, kreują imaginarium bellicystyczne, wojenną choreografię dziejów. Piszę to nieco ironicznie, bo Turek staje się toposem. Oznacza wówczas tylko wojnę. Ten ciąg wyobrażeń nie ma w sobie nic z idiosynkrazji, wrogości. Rozwija się potem w różnych kierunkach. W Reducie Ordona (1832) to Turek wraz $z$ obrońcą Warszawy staje w rzędzie nieprzyjaciół cara na śmierć i życie:

Skinął - padają knuty od Niemna do Chiwy.

Mocarzu, jak Bóg silny, jak szatan złośliwy,

Gdy Turków za Bałkanem twoje straszą spiże,

ku było wówczas 437 domów, $\mathrm{z}$ tego 9 murowanych, 7 murowanych kościołów oraz drewniany meczet tatarski. Nieco inną liczbę, chyba przesadzoną, podawał w swoim Pamiętniku brat poety, Franciszek Mickiewicz, twierdząc, że w Nowogródku było "domów 609, kamienic 21". Według Statystyki Lachnickiego (dane te pochodzą ze spisu w roku 1816) ówczesny Nowogródek liczył 1471 mieszkańców. Większość stanowili Żydzi, których było 726, oraz Tatarzy, których było 319. Jeśli liczby te przeliczymy w stosunku procentowym, to okaże się, że chrześcijan (wszystkich wyznań) było w Nowogródku około 29\%, Żydów i Tatarów zaś razem około 71\%. Te 29\% rzymskokatolickie, prawosławne oraz unickie to 426 osób".

19 Warto tu wspomnieć np. działacza i badacza karaimskiego A. Zają c zk ow s ki e go (Orient jako źródło inspiracji $w$ literaturze romantycznej doby Mickiewiczowskiej. Warszawa 1955) i ze strony żydowskiej J. M a u r e r („Z matki obcej...” Szkice o powiazaniach Mickiewicza ze światem Żydów. Londyn 1990).

20 Tekst ten powstał w latach 1817-1818.

21 Turek. Hasło w: Stownikjęzyka Adama Mickiewicza. T. 9. Red. K. G ó r s ki, S. H r a b e c. Wrocław 1977, s. 212. 
Gdy poselstwo paryskie twoje stopy liże -

Warszawa jedna twojej mocy się uraga,

Podnosi na cię rękę i koronę ściąga,

Koronę Kazimierzów, Chrobrych z twojej głowy,

Boś ją ukradł i skrwawił, synu Wasilowy! [W 334]

To prawda, że heroizacja Warszawy odbywa się tu również kosztem Turków, ale najnędzniejszą kreatura zdaje się $\mathrm{w}$ tym wypadku francuski rząd. Zdecydowanie negatywnie wybrzmiewa obraz Turka w słowach Kaprala z części trzeciej Dziadów (akt I, scena 3):

A to jest rzecz niemała widzieć, jak człek kona.
Widziałem ja na Pradze księży zarzynanych,
I w Hiszpaniji żywcem z wieży wyrzucanych;
Widziałem matek szablą rozrywane łona,
I dzieci konające na kozackich pikach,
I Francuzów na śniegu, i Turków na palu;
I wiem, co w konających widać męczennikach,
A co w złodzieju, zbójcy, Turku lub Moskalu ${ }^{22}$.

Również te refleksy obrazu-stereotypu odnoszace się do okrutnego Turka znajdziemy u Mickiewicza, jednak nigdy nie stał się on dominujący. Cytowane wersy to wypowiedź twardego wiarusa, Kaprala, żyjącego w świecie jasno zdefiniowanych wrogów, z którymi srodze się zmaga. Wydaje się, że o wiele częściej stereotyp Turka i topos wojny z Turcją miał znaczenie mentalne lub... pozytywne. Zauważmy: czyż to nie wojny z Turcją, jak przekonywał orator w Collège de France, miały wytworzyć w Sarmacie silne poczucie narodowości? Stereotyp i topos zastosowane w historiozofii dały zgoła zaskakujący efekt - odświeżyły sensy, pozwoliły ukazać etnogonię polskości.

Trzecie wcielenie mitu tureckiego związane było z przeżyciem zesłania. Podróż na Krym była wędrówką - co Mickiewicz sobie uświadamiał - po rubieżach dawnej Rzeczypospolitej, w świat, który, jak Krym, do Rzeczypospolitej Obojga Narodów w średniowieczu należał. W Sonetach krymskich i w Sonetach odeskich (oba cykle opublikowano w roku 1826) łatwo zdekodować symbolikę wanitatywną, trudniej przyjąc, iż to obraz rzeczywistego świata historii tureckiej, tatarskiej i polskiej od czasów Hadżi Gireja, powstania Chanatu Krymskiego (w roku 1449 został on jego władca). Jest to świat opiewany wierszem przez poetów staropolskich, wpisany w Taurykę Adama Naruszewicza, Pamiętniki Juliana Ursyna Niemcewicza, a potem w relację z podróży Edmunda Chojeckiego - Wspomnienia z podróży po Krymie ${ }^{23}$.

Mówię tylko o Krymie, genialnie zapisanym poetycko: „Jeszcze wielka, już pusta Girajów dziedzina!" (Bakczysaraj. W 240). Ów niewdzięczny Krym Tatarów $\mathrm{i}$ islam to jednak nie wszystko. Uświadomiłem to sobie w sierpniu 2014, oglądając twierdzę Akerman (dziś Biłhorod-Dnistrowśkyj, Białogród nad Dniestrem). Przecież

A. Mickiewicz, Dziady. Część III. W: Dzieła poetyckie, t. 3: Utwory dramatyczne (Oprac. S. Pigoń. 1953), s. 172.

23 A. Naruszewicz, Tauryka, czyli Wiadomości starożytne i późniejsze o stanie i mieszkańcach Krymu do naszych czasów. Warszawa 1805. - E. C h oj e c ki, Wspomnienia z podróży po Krymie. Warszawa 1845. - J. U. N i e m c e w i c z, Pamiętniki czasów moich. T. 1-2. Oprac., wstęp J. D i h m. Warszawa 1957. 
Mickiewicz zwiedzał, podobnie jak Puszkin, przez 300 lat należącą do Turcji olbrzymią fortece położoną między Morzem Czarnym a zatoką, do której wpada Dniestr (liman dniestrowy): „To błyszczy Dniestr, to weszła lampa Akermanu” (Stepy Akermańskie. W 235) ${ }^{24}$. Autor Grażyny był daleko od Krymu, prawie 200 kilometrów, na ziemiach Besarabii. Tu dziedzictwo tureckie - znów z czasów wojen polsko-tureckich - miał na wyciągnięcie ręki: potężne mury, ogromne przestrzenie, wspomnienia oblężeń i bitew. W roku 1484 zdobyli warownię Turcy, od roku 1387 stanowiła ona lenno Polski, w kolejnych wiekach - pod panowaniem Wołochów, Tatarów, Turków. Wreszcie w 1812 roku Akerman włączono do Rosji. Mickiewicz odwiedził go w 1825 roku.

Jeśli pamiętamy Stepy Akermańskie, to, niestety, kojarzymy je tylko z Krymem. Akerman to ta sama przestrzeń kulturowa tatarsko-wołosko-tureckiego Czarnomorza, lecz jakże o d d a l o n a geograficznie od Krymu. Tak więc zesłanie okazało się kolejnym bezpośrednim zbliżeniem Mickiewicza do Turcji - jako fenomenu historycznego. Była to Turcja (ale i Chanat, i Kozacy) pokonana przez Rosję; Turcja, co już przeminęła na północnym wybrzeżu Morza Czarnego ${ }^{25}$. I jeszcze coś: cykl Sonetów krymskich rozpoczyna utwór - Stepy Akermańskie - z Krymem geopolitycznie nie związany, natomiast przynależący do tego samego dominium historii, w którym Turcy, Tatarzy, Polacy i Rosjanie odgrywali kluczową rolę.

\section{„Kulbaczka wąska, modą z turecka kozacką $[\ldots]^{\text {26 }}$}

Przekonuję, że fundamentalne znaczenie miały dla Mickiewiczowskiego obrazu Turcji doświadczenia, a nie lektury. Lecz trzeba w tym miejscu wprowadzić kolejny element pejzażu. Turecczyzna stanowiła bowiem - jako strój, typ broni, pewien obyczaj - część kulturowego dziedzictwa szlachty polskiej27. Mickiewicz ów aspekt podniósł, wydobył, harmonijnie łącząc z elementem historycznym:

Oczywiście, Mickiewiczowi nie chodziło o stworzenie realistycznego dziennika podróży, lecz cyklu zgłębiającego tajemnice bytu, natury, ,ja”.

25 W tym czasie wyobraźnię części elit rosyjskich rozpalała wizja odbicia Konstantynopola $\mathrm{z}$ rąk Turków, a nawet podporządkowania sobie części świata. Zob. A. W a li c k i, Imperialna ideologia Fiodora Tiutczewa. W: Rosja, katolicyzm i sprawa polska. Warszawa 2002, s. 88: „Dał [...] [Tiutczew] upust swym fantazjom ekspansjonistycznym w traktacie Rosja i Zachód (włączającym do obszaru Wschodniego Imperium nie tylko Bałkany, lecz również Węgry i wschodnie Niemcy) oraz w wierszu Rosyjska geografia, napisanym w roku 1848, czyli w okresie największego przypływu wiary w dziejową misję Rosji. Zdumiewający ten utwór formułował taką oto wizję przyszłych granic Rosji:

\footnotetext{
Siedem wewnętrznych mórz siedem wielkich rzek,

Od Nilu do Newy, od Łaby aż do Chin -

Od Wołgi do Eufratu, od Gangesu do Dunaju...

Oto cesarstwo rosyjskie... i nie przeminie ono nigdy,

Zgodnie z prawami Ducha i proroctwem Daniela.
}

P-XI 529. Kulbaczka - 'siodełko'.

27 Zob. tomy zbiorowe: Estetyczne aspekty literatury polskich, białoruskich i litewskich Tatarów lod XVI do XXI wieku) / Aestetic Aspects of the Literature of Polish, Belarusian and Lithuanian Tatars (from the 16th to the 21st Century) / Esteticzeskije aspekty literatury polskich, biełorusskich i litowskich Tatar (XVI-XXI ww.). Ed. G. Czerwiński, A. Konopa cki. Białystok 2015 (tu studia S. Akiner, A. Cudowskiej i M. Dajnowskiego). - Wschód muzułmański w literaturze polskiej. Idee i obrazy. Red. nauk. G. Cze rwińs ki, A. Kon o pa cki. Białystok 2016 (tu rozprawy M. Burzki-Janik, K. Krawiec-Złotkowskiej, R. Krzywego, M. Kurana, M. Ruszczyńskiej, K. Vandenborre). 
tymi wszystkimi wojennymi zapasami Rzeczypospolitej i Porty. Szczególnym przykładem dzieła integrującego w sobie w sposób subtelny wielokulturowe odniesienia jest Pan Tadeusz, w którym nawiązania do tego, co tureckie, niemieckie, rosyjskie, francuskie etc., rozłożone zostaja w strukturze całego poematu tak, że żadne nie dominuje nad innym ${ }^{28}$. Przypomnijmy wybrane watki tureckie, odwołujące się najściślej do depozytu kulturowego starej Polski.

Do historiograficznego toposu wojny z Turkiem odnosi się wezwanie Rosjanina, majora Płuta: „Gotować się do marszu! Pójdziem, czy pod Turka, / Czy na Francuza [...]" (P-I 51). Złożonym odniesieniem aktualizującym zmieszanie wątku tatarskiego $z$ tureckim, a wzbogaconym o aluzję do fałszywej etymologii (Tatar - tartar) są słowa epopei: „A muszą też być $\mathrm{z}$ wami Turki czy Tartary, / Czy syzmatyki, co ni Boga, ani wiary!" (P-XII 560) ${ }^{29}$. Wraca tu stereotyp Turka-poganina, z pełna świadomością przez Mickiewicza uwypuklony. W księdze II wersy: „A młodzież na dziedzińcu biła się w palcaty / Lub ujeżdżała pańskie tureckie bachmaty" (P-II 101) nawiązuja do starej sławy tureckich i tatarskich koni, bachmatów ${ }^{30}$, słynących $\mathrm{z}$,wytrzymałości na głód, pragnienie i trudy"31. Inny wymiar zamiłowań orientalnych - do kawy, przypraw, słodyczy - wydobywa wers kolejny: „Owe ryby! łososie suche, dunajeckie, / Wyzyny, kawijary weneckie, tureckie” (P-XII 547) ${ }^{32}$. W końcu powraca w Panu Tadeuszu pamięć o tryumfach wojennych. Poeta odwołuje się do wspomnianego toposu w finale, w scenie malującej zgodę:

[...] Cały ten sprzęt osobliwy,

Zdobyty $[\ldots]$

Na jakimś bardzo znacznym szlachcicu tureckim,

Przyjm, Asesorze [...]. [P-XI 530] ${ }^{33}$

W twórczości Mickiewicza owych reaktualizacji związków kulturowo-historycznych Polski z Turcja jest znacznie więcej. Wszystkie one - nawet te wojenne - mówią o tradycji, zwyczajach i doświadczeniach historycznych bardzo bliskich szlachcie polskiej. Reaktualizacje te stanowia jej narracyjny skarbiec opowieści wojennych czy podróżniczych (liczne niegdyś relacje z poselstw polskich do Stambułu) ${ }^{34}$ lub uwewnętrzniony element transferu kulturowego między Rzeczpospolitą a Imperium Otomańskim ${ }^{35}$. Sa to nawet silniejsze związki niż funkcjonująca na prawach polskiej wizytówki w Turcji wieś Adampol (Polonezköy) nieopodal

Zob. W. Próchnicki, Niemieckie tropy $w$ „Panu Tadeuszu” Adama Mickiewicza. W zb.: Noc. Symbol-temat-metafora. T. 2. Red. J. Ławski, K. Korotkich, M. Bajko. Białystok 2012. Są to słowa Maćka, skierowane przeciw obcej narodowościowo, „kościoły rabującej” armii Napoleona.

Zapożyczenia z języka tureckiego odnotowywano już w XIX wieku, zob. A. K. Czartoryski, Stowniczek wyrazów przyjętych do mowy polskiej ze wschodnich języków. Lwów 1828.

Bachmat. Hasło w: Z. Glog er, Encyklopedia staropolska ilustrowana. T. 1. Red. K. Piw o cki [i in.]. Warszawa 1958, s. 94.

Przypis Pig o nia do w. 149 (P-XII 547) ",wyzyna", właściwie "wyzina"- mięso wyza, ryby w rodzaju jesiotra, żyjącej w dopływach Morza Czarnego [...]”.

Chodzi tu o zdobycze ze zwycięskiej bitwy Sobieskiego z Turkami i Tatarami pod Podhajcami (1665).

Zob. S. Tw a r d ow s k i, Przeważna legacyja Krzysztofa Zbaraskiego od Zygmunta III do sottana Mustafy. Wyd. R. Krzywy. Warszawa 2000.

Zob. Z. Żyg uls ki jun.: Sztuka turecka. Warszawa 1988; Światła Stambułu. Warszawa 1999. 
Stambułu, założona w 1842 roku przez księcia Adama Czartoryskiego dla polskich emigrantów.

Sarmatyzm wchłonął część obyczajów, strojów, ale też słownictwa tureckiego. Dziedzictwo wielowiekowego wroga stało się, o dziwo, elementem własnej kultury, co w Panu Tadeuszu odnotowano skrzętnie i z uznaniem. A przecież - ów rok 1834 - nie był to jeszcze czas Mickiewiczowskiego entuzjazmu dla Turcji... Tematom tureckim w polskim romantyzmie można by poświęcić obszerną monografię. Są one liczne i, co ważne, niemarginalne. Nie stanowią li tylko orientalnego ornamentu, co przykład tylko Mickiewicza $\mathrm{z}$ jaskrawością ukazuje.

Ponadto oprócz poświadczenia związków kulturowych z epoki sarmackiej romantyzm autora Grażyny wprowadza inny wątek: literackiego orientalizmu. Orient turecki pojawił się u Mickiewicza $\mathrm{z}$ całą siłą w utworze Renegat. (Ballada turecka), z 1824 roku, zreszta literacko niepierwszorzędnej. Nie zgodzę się z opinią, jakoby motyw turecki pełnił tu tylko funkcję ozdobna, był wydobyty powierzchownie. Przypis Mickiewicza do słów „cały dwór klasnął” (w. 30) wskazuje na zamiar i umiejętność budowania orientalnego kolorytu, konsekwentnie doprowadzony do ostatnich wersów ballady: „C ały d wór kla s nął - wyrażenie europejskie; w duchu wschodnim należałoby powiedzieć: cały dwór włożył do ust otwartych milczenia palec podziwu" (W 170).

Najsilniej temat turecki - jako odzwierciedlenie właśnie poetyckiej fascynacji Orientem - wybrzmiał jednak w tłumaczeniu z 1832/33 roku Byronowskiego Giaura. Ułamków powieści tureckiej. Poprzedzony Przemowa tłumacza przekład ów wysoko stawiał Byrona już nie tylko jako pioniera romantyzmu, bo w latach 18521853 nie był to temat wart podjęcia, ale jako poetę metafizycznego: „Wielka zagadka świata, zagadka przeznaczeń rodu ludzkiego, przyszłego życia, stała mu zawsze przed oczyma” (G 155). Owa „zagadkę” rozwiązywał Mickiewicz w Giaurze poprzez wyzyskanie wątków tureckiego, greckiego i weneckiego. Obraz świata tureckiego jest tu, o czym się zapomina, złożony: to poemat „o smutnych losach branki muzułmańskiej, która za niewierność ukaraną została sposobem tureckim, utopiona w morzu, i której zgonu pomścił się kochanek jej, młody Wenecjanin” (G 157). W oryginale Byrona (The Giaour. A Fragment of a Turkish Tale, 1813) znajdujemy jednak słowa o „muzułmańskim sposobie”. To Mickiewicz zmienia tu, turkizuje oryginał:

The story, when entire, contained the adventures of a female slave, who was thrown, In the Mussulman mann ser, into the sea for infidelity, and avenged by a young Venetian [... $]^{36}$.

Podobne zjawisko zauważymy w chwalących obyczaje Wschodu przypisach do Giaura. Gdzie w objaśnieniach Byron wspomina Mahometa, tam Mickiewicz przywołuje Koran i Turków:

Note 12. Page 134, col. 2:

Since his turban was cleft by the infidel'sabre.

I need hardly observe, that Charity and Hospitality are the first duties enjoined by Mahomet; and to say truth, very generally practised by his disciples. The firstpraise that can be bestowed on a chief is a panegyrie on his Bounty; the next on bis valour ${ }^{37}$. 
s. 170 , w. 346 :

Gość płacze dobrodzieja, płaczą słudzy pana.

Ludzkość i litość dla ubogich nakazana jest Koranem muzułmanom. Wyznać należy, że znaleźć można często przykłady tych cnót między Turkami. Zwyczajnie, jeżeli kto chce chwalić Turka, wysławia naprzód jego szczodrotę [...], a potem męstwo. [G 207]

Przekład Mickiewicza, jak wiele wskazuje, konsekwentniej niż oryginał buduje turecka, a nie po prostu wschodnią, orientalną atmosferę. Trudno nie wspomnieć oczywistego kontekstu: Byron wzią udział w greckiej irredencie przeciw Turkom w 1824 roku. Zmarł w Grecji 19 IV 1824, wojując z Turkami, o których, jak polscy szlachcice $z$ epoki sarmackiej, miał pisać jako o godnych, ucywilizowanych nieprzyjaciołach (zob. przypis do w. 341 Giaura o wschodniej gościnności〈G 207〉). Mickiewicz umrze walcząc wraz z Turcją przeciw Rosji, która była protektorem i greckich, i słowiańskich powstań antytureckich, zaskarbiając tym sobie wdzięczność - zazwyczaj skonfliktowanych - Greków i Słowian bałkańskich, pokładających w Rosji nadzieje na odrodzenie państwowe oraz narodowe ${ }^{38}$. Dostrzegamy tu jakiś paradoks historii i egzystencji - miłośnik Byrona, który zmarł walcząc przeciwko Turcji, położy swe wszystkie nadzieje, walcząc wspólnie z Turcją. I tym więc razem wątek literacki niepostrzeżenie przechodzi w historyczny i religijny, pojawiający się w powieści Anglika:

Jeśli śmierć ręką chrześcijan zadana,

Jest Turkom kluczem rajskiego ogrojca,

Tedy do raju wysłał go zabójca. [G 192] ${ }^{39}$

Owe wątki „rajski” i „diabelski” (Iblis) powracają w niezliczonych wersjach i wersach poematów romantycznych, jednak pojawiają się już nie jako tureckie, lecz po prostu związane $\mathrm{z}$ islamem, także arabskim.

Wątek kolejny turkizmu Mickiewicza nieco, ale tylko nieco, zaskakuje. Chodzi o paralelę duchową: wierzący chrześcijanin - wierzący muzułmanin (Turek). Poecie deizm czy ateizm - bądź to Francuzów XVIII- i XIX-wiecznych, bądź to średniowiecznych Mongołów - źle się kojarzyły. Komu niewiarę przypisał, tego równocześnie wypisał ze swych konstrukcji historiozoficznych jako nosiciela wartości, kreatora, podmiot dziejów. W owym poszukiwaniu świadectw wiary Mickiewicz był odważny - zastanawiał się nad religią i mitologią Słowian przed ich wędrówką z Indii do Europy ${ }^{40}$, przywoływał odległe konteksty kulturowo-historyczne (zoroastriański, lapoński, arabski z czasów przed islamem) ${ }^{41}$. Nie dziwi, że wielokrotnie - wprawdzie bez wielkiego entuzjazmu - z niejakim uznaniem wspominał o religijności Turków:

Zob. M. B a j k o, Obraz Greka w powieściach „bałkańskich” Teodora Tomasza Jeża. Rekonesans. W zb.: Filhellenizm w Polsce. Rekonesans. Red. M. B or ow s ka, M. Ka li n ow s ka, J. Ław s ki, K. Tomaszuk. Warszawa 2007. - S. K. Pavlović, Historia Bałkanów (1804-1945). Przeł. J. Pola k. Warszawa 2009. Relacja o śmierci Hassana: „I teraz może hurys czarnooka / Witać Hassana u bramy Proroka” (G 192).

40 Zob. też M. Rudaś - G rodzka, Sfinks słowiański i mumia polska. Warszawa 2013.

41 Zob. wiersze Aryman i Oromaz. Z Zenda-Westy, *** (Lapończycy poganie...), Almotenabby czy parafrazę Szanfary. Kasyda z arabskiego. 
Takim uczuciem Turcji była propaganda Koranu [... $]^{42}$.

W Turcji są niektórzy obdarzeni duchem prorockim i słyszący przyszłe postrzały. [G 212, przypis do w. 1049]

Bo i u Turków sułtan musi szanować prawo Mahometa, ani może go sam wykładać, ale są na to księża tureccy ${ }^{43}$.

nie tylko u Europejczyków, ale i u Turków, i u dzikich można nauczyć się wiele rzeczy potrzebnych ${ }^{44}$.

Dodam, że Giaur w przekładzie Mickiewicza wydobywa inny wątek: wiarę Turków w zjawiska nadprzyrodzone, np. w upiory: „Wiara w upiory powszechna na Wschodzie. Turcy zowia je wardula ch a [...]" (G 211, przypis do w. 731) ${ }^{45}$.

Najpełniejszym uznaniem brzmia jednak cytowane zdania $\mathrm{z}$ arcykatolickich i mesjanistycznych Ksiag narodu polskiego i pielgrzymstwa polskiego (1832) ${ }^{46}$. Jest to pochwała prawa, porządku i wpływu wiary na życie społeczne, które to zjawiska Mickiewicz znajduje u Turków. Turków, podkreślam, czyli ludzi wierzacych, religijnych, ludzi Księgi. Być może - według poety - nie jest to Księga właściwa, ale Koran i Biblia nie stoją w jego myśli na dwóch różnych biegunach. Zdaje się, że są po tej samej stronie - a przeciw ateizującej się cywilizacji Zachodu.

Mickiewicz odkrywa metafizyczny rdzeń obu kultur - polskiej i tureckiej. Najwyraźniej zaś widać to w Stambule, gdzie nie razi go niemal nic, co związane byłoby $z$ islamem. Dodam, że to samo dotyczy Żydów, prawosławnych, Karaimów, Tatarów, Arabów - jeśli ich wiara jest równocześnie ochroną wolności przed zniewoleniami takimi, jak upodlenie $\mathrm{w}$ imperialnym państwie lub nihilizm ${ }^{47}$. Czyż jednak i w tym momencie nie powinniśmy powrócić do Nowogródka i zobaczyć Mickiewicza, chłopca, który obserwuje modlących się Tatarów w meczecie, Żydów w synagodze, chrześcijan w ich różnorakich świątyniach? Tam to się zaczęło.

\section{„Sprawa”, także polityczna...}

Dopiero uwzględniwszy te wszystkie przemiany doświadczeń Wschodu, Turcji i turecczyzny - a bohater Pana Tadeusza chciał nawet „Wynieść się gdzie na Moskwę lub na Tatarszczyzę ${ }^{48}$ " (P-X 480) - można powiedzieć o historiograficznej/historio-

A. M i c ki e w i c z, O duchu narodowym. W: Dzieła. Wyd. Jubileuszowe. T. 6: Pisma proza. Część II. Oprac. L. Płoszewski. Warszawa 1955, s. 67.

A. Mi c ki ew i c z, Ksiegi narodu polskiego [...]. W: Ksiegi narodu polskiego i pielgrzymstwa polskiego. Oprac. M. Grabow ska. Warszawa 1986, s. 34. Zdania te padają na samym początku Ksiag!

A. Micki ewicz, Ksiegi pielgrzymstwa polskiego. W: jw., s. 64.

Następne zdanie o upiorach: „Grecy równie ich się boją i mnóstwo o nich prawią strasznych powieści” (G 211, przypis do w. 731).

Ksiegi narodu polskiego bywają nazywane przy tym „antyżydowskimi”. Zob. A. G. D u k er, Adam Mickiewicz's Anti-jewish Period. Studies in "The Books of the Polish Nation and of the Polish Pilgrimage". W zb.: Salo Wittmayer Baron Jubilee, Volume on the Occasion of His Eightieth Birthday. Ed. S. Li eberman. T. 1. Jerusalem 1974.

Zob. A. G. D u ker, Jewish Volunteers in the Ottoman-Polish Cossack Units during the Crimean War. „Jewish Social Studies” 1954, nry 3-4. - D. V a sili e v, La Turquie dans les coeurs de deux poets. Pouchkine et Mickiewicz. W zb.: Mickiewicz - Turcja - Europa.

W autografie: „Tureczczyzna”, w wydaniu S. Pigonia czy K. Górskiego: „Tatarszczyzna”. 
zoficznej oraz politycznej roli Turcji. U Mickiewicza wątki historiograficzne niemal od razu przechodzą w historiozoficzne.

Turcja historyków pojawia się w czasach szkolnych, ale już w Objaśnieniach do poematu opisowego „Zofijówka” znajdziemy ciekawą informację o Odessie: „Po traktacie Rosji z Turcja roku 1792, dla obrony nowych granic otworzony port nad Morzem Czarnym" ${ }^{49}$. W ogromnej mierze dawne motywy tureckie przenikna potem do niedokończonej Historii polskiej (ok. 1834-1836), najdłuższego prozą polską pisanego tekstu Mickiewicza, gdzie Turcy sa ludem wędrowców zmierzających z centralnej Azji do Azji Mniejszej. Wątki tureckie zazębiają się tu z bizantyjskimi. Jako źródła zmoskalonego prawosławia Mickiewicz nie cierpiał Bizancjum i Konstantynopola także dlatego, że była to kultura rodem z Grecji, zastępująca żywą wiarę w Boga sofizmami i logiką (również teologiczną) ${ }^{50}$. Znajdziemy w Historii polskiej i zaskakujące tezy: „plemiona Lechów [...] pomieszały się z plemionami tureckimi i mongolskimi [...]" (! ${ }^{51}$. Potem apogeum tematu tureckiego - jak i wielu pokrewnych - stanowić będa prelekcje paryskie. Tu wszystkie wątki historiozoficzne ulegna przekształceniu w historiozofię mesjanistyczną. Jak pisałem, polska etnogonia dokona się z udziałem tego bitnego wroga, bliskiego przeciwnika, jakim była Porta.

Ostatnim epizodem omawianych przekształceń tureckiego obrazu stanie się wątek polityczny, związany z wojną krymską. W Turcji pokładał Mickiewicz ogromne nadzieje. Jechał tam jak do kraju, który - przez Morze Czarne - jest bliskim pomostem do ziem polskich. Uczył się języka tureckiego i zarazem politykował ${ }^{52}$. Listy z owego okresu zawierają liczne wzmianki o Turkach i Turcji jako najważniejszym w tamtej chwili podmiocie polityki światowej. Nie drażniło poety przechodzenie Polaków na islam. Ani Michała Czajkowskiego, ani generała Józefa Bema za to nie krytykował ${ }^{53}$. Irytowały Mickiewicza intrygi Hotelu Lambert skierowane przeciw

49 A. Mickiewi cz, Objaśnienia do poematu opisowego „Zofijówka”. W: Dzieła, t. 5: Proza artystyczna i pisma krytyczne (Oprac. Z. Dokurno. 1996), s. 138. Z ostatnich studiów nad etapem odeskim w życiu Mickiewicza zob. następujące artykuły opublikowane w zbiorze Odessa $w$ literaturach słowiańskich. Studia / Odiesa w słowiańskich literaturach. Studii / Odessa in Slavonc Literatures. Studies (Red. nauk. J. Ławs ki, N. Maliutina. Białystok-Odessa 2016): J. J u s zkiewicz, Odessa $w$ listach Adama Mickiewicza: 1825-1829. - Z. Kaźmierczyk, Odessa filomatów. - J. Ławski, Polskie mitologie Odessy. - K. Puzi o, Odessa w polskich dziewiętnastowiecznych relacjach z podróży odbytych między 1814 a 1843 rokiem. - G. To m a s z e w s k a, Motyli przystanek. Odessa Mickiewicza. („Dumania w dzień odjazdu”).

Zob. J. Ław ski, Bizancjum Mickiewicza. Cesarstwo Wschodnie w „Pierwszych wiekach historii polskiej”. W zb.: Antyk romantyków. Model europejski i wariant polski. Rekonesans. Red. M. Kalinowska, B. Pa procka-Podlasiak. Toruń 2003.

51 A. Mickiewi cz, Pierwsze wieki historii polskiej. W: Dzieła, t. 7 (Oprac. J. Maśla n ka. 1999), s. 31 .

52 Zob. T. Kowalski, W. Zają czkowski, Kilka próbek pisma perskiego i tureckiego Adama Mickiewicza. W zb.: Miscellanea z okresu romantyzmu. Red. S. Pi goń. Wrocław 1956.

53 Z najwyższym uznaniem pisał A. M i c ki e w i c z do Z. Szymanowskiej w liście z 25 X 1855 (L 377 ) o Hipolicie Kuczyńskim (1818-1858), czyli Iskinder Beyu, podpułkowniku armii egipskiej: „Może przypomnisz sobie Kuczyńskiego. Bywał u mnie często na Batignolles. Marynia go widywała, kazał oświadczyć jej ukłony. Jest on teraz pułkownikiem Arabów i szefem sztabu wojsk egipskich. Nie poznałbym go. Czarny jak Arab i wszystkie ma ruchy beduińskie. Człowiek niepospolity; jeśli pożyje, daleko zajdzie". 
pułkom kozackim Sadyka Paszy. Pisał z Konstantynopola, w liście z 25 X 1855, do Ludwika Lenoira-Zwierkowskiego tak:

Biedny Sadyk, nosi on cięższy krzyż niż wszyscy pobożni stronnicy p. Zamoyskiego. Nie uwierzysz, ile on pracuje. Przez dwa tygodnie pobytu, prawie pod jednym namiotem, nie widziałem go nigdy śpiącym ani drzemiącym. Po musztrach i polowaniu, i wieczerzy z kolegami pisze i dyktuje do świtu, i ciagle głos jego po obozie słychać. A tu mu tymczasem nowe coraz trudności sami rodacy tworza.

Nieszczęściem jest i to, że książę Władysław wedle instrukcji p. Zamoyskiego zda mi się działać; wedle niego o ludziach i rzeczach sądzi; na jego tryb postępuje. Robiono tu uwagę, i sprawiedliwą, że na Wschodzie należało było księciu inaczej tu zaraz wystapić. Jeśli człowiek zasłużony i znany może czasem formy zaniedbać, młodemu Panu $\mathrm{z}$ wielkim imieniem nie wypadało przedstawiać się na sposób, w jaki tam wizyty urzędowe oddawał. Wymagano nieco okazałości, mianowicie wobec Turków. Słyszę tu zewsząd, że pan Zamoyski, który tu ma reputację wielce skąpego, musiał w tym względzie złe rady dać księciu. Ale co pomogą skargi po szkodzie. [L 375]

Zauważmy, iż Mickiewicz wytykał młodemu księciu Władysławowi Czartoryskiemu nieumiejętność pokazania się wobec Turków, skạstwo, nieznajomość stambulskich zwyczajów. Turcja dzieliła - jako państwo podupadłe, na krawędzi rozpadu - podobny los z Polską. W niezwykły sposób lawirował Mickiewicz, pragnąc zarazem wzmocnienia Turcji, ale i przyciagnięcia Słowian bałkańskich do obozu antyrosyjskiego, najchętniej widzących Turcję pokonaną ${ }^{54}$. Wzór zwycięstwa dała w 1822 roku Grecja, której z kolei ciż sami Słowianie nie znosili jako kolonizatorki, sprawczyni duchowego ucisku ${ }^{55}$. Rzeczy te w 1855 roku dopiero się zaczynały ${ }^{56}$. Mickiewicz umarł na cholerę. Wojna krymska nie spełniła politycznych rachub Polaków.

Listy pisarza stanowią świadectwo niesłychanego rozgorączkowania spowodowanego sprawą polską, do której klucze znajdowały się, zdaniem wszystkich, właśnie w Turcji. Więcej: zazębiły się tu interesy angielskie, francuskie, rosyjskie, polskie. Dla poety był to jednak - przyznajmy: i dziś nieprawdopodobny z kulturowo-politycznej strony - splot spraw polskich, tureckich, żydowskich i słowiańskich. Węzeł lub raczej wizja wspólnej misji wyzwolicielskiej polsko-turecko-żydowskosłowiańsko-francusko-angielskiej. Aż tyle, i o tym mówią prawie wszystkie listy poety... Np. z 5 XI 1855, z Konstantynopola, do Michała Czajkowskiego:

Pisałem do Paryża w celu, aby dać poznać Francuzom teraźniejszy tutejszy stan rzeczy; jaki stąd będzie skutek, doniosę. [...]

Rzecz, którą tu p. Lévy ${ }^{57}$ prowadzi z Izraelitami, rozwija się pomyślnie. Wielu tu obiecuja pomoc. Radzi są, że p o c zą tek zrobiony i że przez paszę tureckiego ${ }^{58}$, przychylnego Izraelitom. Rzecz ta jest Zob. E. Możejko, Iwan Wazow. Warszawa 1967. - M. Grigorowa, Oczite na słowoto. Połonisticzni studii. Weliko Tyrnowo 2014.

Zob. jako kontekst: K. K o r o t k i c h, Ignacego Pietraszewskiego podróże na Wschód i do Konstantynopola. W zb.: Bizancjum, prawosławie, romantyzm. Tradycja wschodnia w kulturze XIX wieku. Red. nauk. J. Ławski, K. Kor otkich. Białystok 2004.

Zob. H. Batow ski: Państwa batkańskie. 1800-1923. Zarys historii dyplomatycznej i rozwoju terytorialnego. Kraków 1938; Mickiewicza misja naukowo-literacka w r. 1855. Warszawa 1955. czącego o wolność narodów. Zob. też J. W. B o r ej s za, Sekretarz Adama Mickiewicza. Armand Lévy i jego czasy 1827-1891. Wyd. 3, uzup. Gdańsk 2005. 
wagi wielkiej dla nas. Znasz to dobrze i podobno, jeden z Polaków będących na wyższym stanowisku [...] żąda do pomocy owego Izraelitę ${ }^{59}$, o którym mówił $\mathrm{z}$ tobą w obozie. [L 382]

Widać tu znów tę drogę od domowego doświadczenia wielokulturowości do praktyki politycznej. Od historiozofii mesjanistycznej (theōria) do działania polityczno-wojskowego (praxis). Od zainteresowania Turcją i Turkami do przedsiębrania wspólnych misji. I to pomimo bardzo ciężkich warunków mieszkaniowych - pisał Lévy do Władysława Mickiewicza 4 XI 1855 o „wystawianiu się „na pastwę pcheł, pluskiew i komarów, a nawet i skorpionów [...]" - pomimo nawet niechęci duchownych tureckich, by Mickiewicz zamieszkał w przyzwoitej dzielnicy ${ }^{60}$. To nie zrażało poety. Ważna była Sprawa, już nie tylko Boża, ale polska i turecka, słowiańska i żydowska. Sprawę tę definiował Mickiewicz zawsze przez kategorię Wolności, wolności bycia we własnej wspólnocie i kultywowania jej tradycji. Po wiekach ta Sprawa zjednoczyła Polaków i zagrożonych przez Rosję Turków.

\section{Smutki baszy}

I na koniec dopowiedzenie egzystencjalne. Jeszcze na długo przed 1855 rokiem Turcja pojawiła się w pismach Mickiewicza jako figura zmagań egzystencjalnych. Zrazu - nieco ironicznie, humorystycznie. W rozprawie, jaka jest artykuł $O$ krytykach i recenzentach warszawskich (1829), wymienił poeta Turków razem z Rzymianami i Amerykanami, pastwiąc się $\mathrm{z}$ sarkazmem w przypisie nad fałszywymi wyobrażeniami twórców i krytyków warszawskich o narodowości literatury...

U nas teraz, nawet po pracach samego Niemcewicza, Czackiego, Lelewela, Bandków, jeszcze wielka kompozycja historyczna, epopeja lub drama, na długie czasy zostanie przedsięwzięciem nad siły poetów, kiedy jeszcze tak mało pomniejszych narodowej poezji rodzajów rozwiniono. O tych rodzajach niektórzy teoretycy i czytelnicy dotąd jeszcze dziwne mają wyobrażenie. Myślą na przykład, że miejsca pospolite, maksymy i morały, $\mathrm{z}$ równą emfazą od Greków, Rzymian, Turków i Amerykanów na teatrze francuskim deklamowane, potłumaczone na polskie gładkim wierszem, jeśli się zaczynają od słów: "Jakiż mię zapał porywa - Muzo, wspieraj mój lot” itp., robi się z tego narodowa oda; jeżeli zaś pokrajane w dialog, włożą się w usta Samborom, Jaksom, robi się narodowe drama; jeżeli na koniec wychodzą na świat w kształcie poematu, noszącego tytuł na -ada, zaczynającego się od ,ja śpiewam" z przydaniem potrzebnych alegorii i tak nazwanych machin, tworzą wtenczas narodową epopeję ${ }^{61}$.

Ów ironiczny fragment wyrażał nadzwyczaj wiele z najbardziej osobistych uczuć poety urażonego zjadliwością krytyki - autor arcydzieł romantycznych, których krytyka zapóźniona w Warszawie, a tak już nowoczesna w Rosji, nie pojmuje. To była prawdziwa furia Mickiewicza, furia intymna zranionego geniusza.

W tym samym czasie na świat wychodzą Sonety odeskie, świadectwo libertyńsko-rokokowego życia poety na tak „słodkim” zesłaniu, jakim okazały się Akerman, Krym i nade wszystko Odessa. Jak pamiętamy, Mickiewicz oceni ten okres, używając orientalnej metafory - powie, że żył niczym basza turecki. To nie tylko me-

Zapewne chodzi o Michała Hor en ste in a (zm. 1868), protegowanego L. Śniadeckiej, nielubianego przez M. Czajkowskiego, czynnego w sprawie zamierzonego legionu żydowskiego.

60 Cyt. za: K. Ko s t e n i c z, Ostatnie lata Mickiewicza: styczeń 1850-26 listopada 1855. Warszawa 1978, s. 496.

61 A. Micki ewicz, O krytykach i recenzentach warszawskich. W: Dzieła, t. 5, s. 190, przypis. 
tafora: Rosja, Krym, Odessa dały mu satysfakcję jako docenionemu poecie, rozchwytywanemu rozmówcy, adorowanemu przez kobiety kochankowi. I jako mężczyzna, i jako poeta poczuł się doceniony (może aż w nadmiarze, stąd potem rozrachunki z Rosją...):

W Odessie prowadziło się życie orientalne, a po prostu mówiąc, próżniackie. Ale widziałem Krym! Przetrzymałem tęgą burzę morską i byłem jednym z kilku zdrowych, którzy zachowali dosyć siły i przytomności, aby napatrzyć się do woli temu ciekawemu widowisku. Deptałem chmury na Czatyrdahu (podobno Trapezie starożytnym) ${ }^{62}$. Spałem na sofach Girajów ${ }^{63}$ i w laurowym gaiku w szachy grałem z klucznikiem nieboszczyka Chana. Widziałem Wschód w miniaturze ${ }^{64}$.

Choć w sonetach miłosnych tryumfuje Petrarka, trudno nie zauważyć, że i w nich znajdujemy coś wschodniego. Czy apologię „rozkoszy”? A może są one ucieczką przed Wschodem w nudny świat kupiecko-salonowych gierek miłosnych, bo „Zboże tanie, deszcz pada, w Grecyi rozboje” (Do wizytujacych. W 229). Mickiewicz-basza nie tłumaczył się z tureckich rozkoszy Krymu i Odessy, hardo napadał i na niedawne kochanki, i na krytyków ${ }^{65}$. Powiedziałbym: był w tym na wschodni sposób okrutny jak autokrata, nie oszczędzający nawet przyjaciół: Czeczota, Zana, Odyńca.

Egzystencjalny i duchowy wymiar doświadczenia Turcji powrócił, co jasne, w 1855 roku. Poeta zostawiał we Francji dzieci, do których tęsknił. Nie wybierał się na wycieczkę. Wyjazd postrzegał jako misję. Podróże z Marsylii do Stambułu, a potem ze Stambułu do Burgas i z powrotem pełne były euforii i obaw ${ }^{66}$. Ale Mickiewicz się nie wahał i nie oszczędzał. To właśnie przypłacił życiem. Korespondencja ze Stambułu obfituje w doniesienia „Jestem zdrów, moja Maryniu” (L 396); jak na ironię, to ostatni znany nam list do córki Marii z 15 XI 1855 (śmierć przyjdzie 26 XI). Troska o dzieci miesza się z chaosem uczuć, jakie wywołuja sprawy polskie: nadziei posuniętej aż do euforii, rozczarowania i złości wywołanych warcholstwem emigracji. Ostatni list Mickiewicza - do Władysława Czartoryskiego z 19 XI - jest smutnym, ale i bezlitosnym „wygarnięciem” księciu żałosności jego zabiegów w Stambule, siły, z jaką skłócał i niszczył emigrację:

W chwili kiedy postrzegłem, na co się zanosiło, przedstawiałem wam w namiocie w Burgas potrzebę, abyście rozmówili się s z c z e r ze z Sadyk-Paszą. To zbyliście milczeniem. Przezierając coraz lepiej, oświadczyłem, że odkrywa się ze strony p. Zamojskiego i waszej widoczny zamiar wytrącenia Sadyka z jego pułkiem ze stanowiska, na którym tyle wam usłużył i tyle mógł być pożytecznym Polszcze; że godzicie na to, aby Sadykowi wydrzeć wszelkie środki działania w Turcji i pozbawić go razem opieki obcych rządów. Na to ani słowa odpowiedzi z waszej strony. Nie było już wątpliwości, żeście przyjechali byli $z$ gotową instrukcją p. Zamojskiego, $z$ wyostrzonym na Sadyka-Paszę nożem. W takim razie należało otwarcie przeciwko niemu wystapić. Jeśliście go uznali nieużytecznym nadal, lub szkodliwym,

Czatyrdach jest górą mającą kształt trapezu.

Chodzi tu o dynastię chanów krymskich.

A. Mickiewicz, list do J. Lelewela, z 7/9 I 1827 (Moskwa). W: Dzieła, t. 14: Listy. Część pierwsza: 1815-1829 (Oprac. M. Dernałowicz, E. Jaworska, M. Zielińska. 1998), s. 392. Pokazuje to jego korespondencja, spór z Czeczotem, Lelewelem.

Zob. J. Ław ski: Konstantynopolitańskie doświadczenie duchowe Adama Mickiewicza. W zb.: Dziedzictwo chrześcijańskiego Wschodu iZachodu. Między pamięcia a oczekiwaniem. Red. U. Ci i rni a k, J. G r a b ow s ki. Częstochowa 2006; Marsylia-Stambut. Śródziemnomorska podróż Adama Mickiewicza. W zb.: Adam Mickiewicz $w$ kontekstach kulturowych dawnych $i$ wspótczesnych. Red. J. Jokiel, M. Burzka-Janik. Opole 2012. 
należało wezwać go, aby ustapił godniejszemu, lepszemu. Wolno wam było rozprawiać się z Sadyk-Paszą, rozpierać się z nim, walczyć z nim, ale nie godziło się pod jego dachem i u jego stołu knuć przeciwko niemu po cichu. Polacy tak nie czynią. Arab pod namiotem gość, przeciwko gospodarzowi nie konspiruje. [L 403] $]^{67}$

Jest to też wymiar egzystencjalny doświadczenia Turcji. Ta ostatnia staje się szybko utracona szansą, bynajmniej nie dzieje się tak dlatego, że kraj ten nie chce pomagać Polakom. Dlatego że Polacy nie potrafią pomóc sami sobie, unurzani w intryganctwie. To Mickiewicza przygnębiało, ale do ostatniego dnia misji konstantynopolitańskiej nie odebrało mu wiary w jej sens. I to pomimo złych przeczuć, tęsknoty do dzieci, o których myślał tak, jakby był gdzieś niedaleko Paryża... W cytowanym już liście do córki pisał:

Władysławowi powiedz, aby zawiesił wszelkie dalsze zamiary aż do czasu, kiedy uzyska baccalauréat. Lekcje jazdy i fechtów bardzo mu potrzebne, niech ich nie zaniedbuje. Jeśli repetycje Olesia tylko pięć franków miesięcznie kosztują, poproś Ciotki ${ }^{68}$, żeby mu je zapewnić. Spytać jednak trzeba wprzódy u p. dyrektora, czy sa potrzebne. [L 396]

Stambuł przyniósł Mickiewiczowi gorycz. Ale dał też nieprawdopodobną nadzieję, szczególnie w obrazie wielonarodowych wojsk Sadyka Paszy, które pojechał oglądać do Burgas.

Zgryzoty nie przesłoniły jednak, jak sądze, pozytywnego wymiaru tego ostatniego doświadczenia Turcji i świata w ogóle. Że świata doświadczył Mickiewicz po raz ostatni poprzez Turcję, to, jak przekonuję, było całkiem naturalne i przez niego oczekiwane $z$ euforia oraz ze spokojem.

\title{
Dom ironii
}

Poczuł się w Stambule jak w Wielkim Nowogródku: identyczny bałagan, ten sam wielonarodowy tłum. Tak kulturowo - z pozoru i faktycznie - daleka Turcja okazała się swojska, domowa, bliska. Rzeczywiście było to to samo theatrum historii, którą tworzyli dawni Sarmaci, bijąc się z Turkiem. I go zwyciężając. Cytowany w motcie Szemiot pochodzacy ze Żmudzi i Podlasia, wprost żądał od Austrii wdzięczności za czyny Jana III...

\author{
Obronny Wiedniu! Przecie oblężony \\ Tak, żeś mało w proch nie był obrócony, \\ Pytam się: komu masz za uwolnienie \\ Dziękować i za zdrowia przywrócenie? ${ }^{69}$
}

W wieku XIX nie było nikogo, kto nie przypominałby o tym sardonicznym śmiechu historii: ratowana przez Sobieskiego Austria rychło stała się drapieżca i roz-

Zob. też P. Wi e r z bi c ki, Działalność Sadyka Paszy w czasie wojny krymskiej na tle jego relacji z obozem Czartoryskich. W zb.: Polacy i ziemie polskie w dobie wojny krymskiej. Red. J. W. B o r ejsza, G. P. Bąbiak. Warszawa 2008.

68 Chodzi o Zofię Szymanowska, przyrodnią siostrę Celiny, zmarłej żony Mickiewicza.

69 S. S. Sz e mi ot, Wesołe, lubo raptowne echo szczęśliwej i od wieków niesłychanej wiktoryi nad Turkami pod Wiedniem, die 12 Septembris Anno 1683, przez najjaśniejszego króla polskiego Jana III otrzymanej. W: Sumariusz wierszów, s. 237. 
bierała Rzeczpospolitą wespół z Rosją i Prusami. Co również Mickiewicz w Księgach narodu polskiego wspominał $\mathrm{z}$ jadowitym wyrzutem:

[...] Maria Tere s a nosiła imię najpokorniejszej i niepokalanej Matki Zbawiciela, aby wyśmiać pokorę i świętość.

Bo była diablicą dumną i prowadziła wojnę dla podbicia ziem cudzych.

I była bezbożną, bo modląc się i spowiadając się, zabrała w niewolę kilka milionów bliźnich. [...]

A ten Józef austriacki podwiódł matkę własną do złego, i braci Polaków, którzy cesarstwo jego od niewoli tureckiej obronili, zabrał w niewolę ${ }^{70}$.

Wojny z Turcją skończyły się pyrrusową wiktorią. Zwycięzca musiał szukać ratunku u pokonanego Turka, a uratowany Austriak zmienił się w zaborcę. Wołał August Antoni Jakubowski:

Nikczemny Wiednia orle, znowu skrzydła swoje

$Z$ carskim ptakiem złączyłeś - leć na krwawe boje,

Ale cię w drodze piorun mej zemsty uderzy ${ }^{71}$.

Mickiewicz chciał już tylko jednego: wielkiej wojny o wolność ludów. Jej oznaki widział w 1855 roku w Turcji. Lecz nie przyniósł jej ani 1855, ani 1863, ani 1872 rok.

Trzeba było czekać. W Turcji i z dala od niej.

\author{
Abstract \\ JAROSŁAW ŁAWSKI University of Białystok \\ HOUSE ENEMY AND ALLY ADAM MICKIEWICZ'S TURKEY
}

The author of the study points at an immense significance of Turkey not only in a literary picture of the world of the most eminent polish romantic poet, Adam Mickiewicz (1798-1855). He grew up in Navahrudak, on the territory of present Belarus, where the Tatars, connected to Turkish and Polish culture, made a strong group, and died during the Crimean War in Istanbul, where he went as a political emissary. Mickiewicz's picture of Turkey was abundant in ambivalence. It received its full development in his lectures at Collège de France in Paris. He depicted Turkey as a historical enemy with which the Polish Republic waged wars, but also as the only country that, as the historical myth upholds, did not recognise the partitions of Poland. In the poet's works, especially in their lexis, the influence of Turkish culture is quite marked and, e.g. in clothes and in militaria, significantly affects the Polish nobility.

70 Mickiewicz, Księgi narodu polskiego, s. 43.

71 A. A. Jaku bow ski, Alopeus. W: Poezje. Z rękopisu wydał i wstępem opatrzył J. Maślanka. Kraków 1973, s. 9. Pod wierszem widnieje data: „Lwów, 3 maja 1833”. 